Island Studies Journal, Vol. 7, No. 1, 2012, pp. 69-98

\title{
Islands and Islandness in Rock Music Lyrics
}

Daniele Mezzana

CERFE (Centro di Ricerca e Documentazione Febbraio '74)

Rome, Italy

daniele.mezzana@cerfe.org

Aaron Lorenz

Law \& Society, Ramapo College

New Jersey, USA

alorenz@ramapo.edu

and

Ilan Kelman

Center for International Climate and Environmental Research - Oslo (CICERO)

Oslo, Norway

islandvulnerability@yahoo.com

ABSTRACT: This paper presents a first exploration, qualitative in character, based on a review of 412 songs produced in the period 1960-2009, about islands in rock music as both social products and social tools potentially contributing to shaping ideas, emotions, will, and desires. An initial taxonomy of 24 themes clustered under five meta-themes of space, lifestyle, emotions, symbolism, and social-political relations is provided, together with some proposals for further research.

Keywords: abductive method; art; islandness; rock music; social construction

(C) 2012 Institute of Island Studies, University of Prince Edward Island, Canada

\section{Introduction: Rock Music and Islands: Looking for a Link}

"[...] in an age when nothing is physically inaccessible or unknowable, the dream of the small, remote and undiscovered place has become so powerful" (Gillis, 2004: 148)

This article presents a first exploration, qualitative in character, of how rock music lyrics and song titles portray islands, islandness, and island features. It examines the island aspects of a socio-cultural trend expressed in as far-reaching a medium as that of rock music. Here, we adopt a broad definition of 'rock music', including different expressions of this genre, starting with the emergence of rock in the late 1950's to early 1960's, and moving towards more current expressions including art rock, progressive rock, punk and reggae (Wicke, 1990; Charlton, 2003). This wide scope is partly mitigated by our focus on Anglophone rock music which, even though historically constituting the bulk of rock music 
and its accompanying lyrics (Curtis, 1987; Charlton, 2003), far from exhausts the range of languages in which rock music lyrics appear ${ }^{1}$.

We also specifically choose to focus on rock music lyrics and song titles, neglecting other dimensions of analyzing rock music, such as the names of bands, their locations (e.g. from the Isle of Wight or Singapore), or album covers [e.g. the album "An Evening of Yes Music Plus" (1993) by Anderson Bruford Wakeman Howe (ABWH) features Roger Dean's painting "Floating Islands"].

This paper contributes to island studies by focusing on social representations (Farr \& Moscovici, 1984) of islands. Such studies seek information about how a given society or social group perceives, interprets, and represents islands in its own experience. Islands, or specific ideas about the characteristics of islands, are often used to give a shape to wider myths, symbols, emotions, feelings, projects and ideologies (Baldacchino, 2007; Hay, 2006).

As elaborated below, rock music expresses social representations that have been developed mostly within the context of a global urban culture (Anckar, 2008). This culture has a strong mainlander component, even when discussing islands. As discussed below, separating the mainlander and islander components in rock music is problematic, even more so than other genres for which such a separation has been discussed (e.g. Baldacchino, 2011; Connell, 1999).

This paper's next section presents an overview of some aspects of the relationship between islands and rock music along with the theoretical elements forming the basis of this work. Then, we detail the methodology and empirical basis for this study. The core results section presents the themes and thematic clusters emerging from this analysis. Finally, in discussing this study's results, we identify avenues for future research in this field.

\section{Some theoretical and critical aspects}

Islandness is interpreted as a physical and social phenomenon (e.g. Baldacchino, 2004b, 2007; Holm, 2000; deCerteau, 1984) as well as a tool through which social reality is negotiated and constructed by people to give shape to ideas and desires (e.g. Thomas 2010; Deleuze, 2004; Deleuze \& Guattari, 1986; Berger \& Luckmann, 1966). In this sense, islands can become cognitive objects, which are loaded with specific meanings in different contexts and occasions (e.g. thematic issues in Geografiska Annaler, Series B: Human Geography, 2005; Geographical Review, 2007), becoming a staple of the human imagination (Cheadle, 2009). Although the notion of 'island' can be problematic (Royle, 2007; Baldacchino, 2008), there are many songs that talk about, or refer to islands, confirming the significance of islands in contemporary Western imagination.

The social importance of music has been addressed by many scholars and writers, including Plato, Rousseau, Nietzsche, and Adorno. Music has always been implicated in the social and political world (Leyshon et al., 2001). Its power to affect, disturb, rouse, and subdue has been the concern of governments and political movements throughout history. The

\footnotetext{
${ }^{1}$ For example, in Italy, a focus on the theme of the islands is present in the lyrics of PFM (Premiata Forneria Marconi), in albums such as "L'isola di niente" ("The Island of Nothing") (1974) (lyrics by Pete Sinfield and Mauro Pagani) or "Ulisse” (“Ulysses”) (1997) (lyrics by Vincenzo Incenzo).
} 
more socially involved a society is, the more active its music tends to be (Said, 1992). Music is able to define and reinforce the existence of power. It can simultaneously present an ideology while remaining open to interpretation. It is a potent force in the construction of national geographies, cultural identities and social norms, to the extent of cultivating a sense of citizenship (Stradling \& Hughes, 1993). Music is also a form of social critique, at times questioning accepted structures and challenging rather than presenting ideologies.

Rock music's powerful form of expression hits the listener metaphorically and inspires passion, e.g. Bob Marley's Trenchtown Rock (1971), "one good thing about music when it hits you feel no pain, so hit me with music". Such music also helps to reinforce the bonds of social integration; e.g., music originating from island parts of the African diaspora, such as the Caribbean, can be an expression of powerlessness and class inequality (Braithwaite, 1979). Music is often a metaphor of socio-cultural processes, explaining how people interact across cultures. Just as the term "world music" is not adequate to describe its critical purpose and the term "rock music" has ambiguities and controversies, "island music" is equally complicated and rich (e.g. Baldacchino, 2011; Dawe, 2004) especially in its connection to island identity (e.g. Connell, 1999).

By focusing on rock music lyrics and song titles, we see both the formal and symbolic meaning immanent in the combination of music and words (Manderson, 2000). The lyrics potentially exemplify social and cultural form, assisting us in understanding islandness through rhetoric, metaphors, images and symbols.

Nevertheless, music is not simply sounds and words. As Bob Marley reminds us, "music gonna teach "dem one lesson" (1971): music can teach; but it can also influence what the lesson should be about. The representation of 'the island' can be similarly skewed.

\section{The Method and its Empirical Basis}

Thus, representations of islands and islandness are considered here as both social constructs and as tools for the social construction of reality, able to impact on and orient knowledge, emotions and action. This study aims to identify, with reference to a limited number of songs, the features and connotations emerging around islands and what are purported to be island characteristics.

Songs were considered to be relevant for this study if they had lyrics in English, had been released between 1960 and 2009, and were accepted in the literature as being part of rock music or which were identified in web portals and websites specializing in rock music lyrics $^{2}$. To be included in the analysis, the title or lyrics (conventionally, from now on we will use the inclusive term "lyrics") had to contain at least one mention of the words "island", "islands", "isle", or "isles". This decision provided a clear reference point, in this case lexical, to anchor possible qualifications and connotations, as discussed below.

The aim was not to have a complete inventory of all lyrics, but an empirical basis large enough to test and to draw out some basic information for an exploratory study, while being fully aware that this has inevitably led to choices and exclusions of various kinds.

\footnotetext{
${ }^{2}$ These web portals and websites include: Rock lyrics (http://lyrics.rockmagic.net/lyrics), PoemHunter.com (www.poemhunter.com), SongLyrics (www.songlyrics.com), All the lyrics (www.allthelyrics.com).
} 
Taken together, the lyrics studied here could be considered to be a convenience sample, particularly suitable for a pilot and qualitative study like this one: a particular type of "nonprobability sample" in which units (in our case, lyrics) are selected on the basis on easy access and availability (Freedman et al., 1998; Powell, 2010). While arbitrariness cannot be avoided in this type of procedure, we have used multiple sources, included songs from different time periods, and examined a reasonable quantity of songs. Cross-checks were carried out on several artists, to verify the adequacy of the chosen sources for the lyrics.

The resulting database includes 412 rock music songs representing the corpus on which we worked. They were entered into a database with the following information: artist; title of the song; the album; year of release; and full text of the lyrics. The list of 412 songs is provided in an Appendix, available from the Island Studies Journal website at: www.islandstudies.ca/node/366/

In chronological order of release, the first song of the collection is "Surfin' Safari" by the Beach Boys (1962) (“...We're going on safari to the islands this year..."). The most recent one is "Christmas Island" by Bob Dylan (2009) ("... How'd ya like to stay up late, like the islanders do? ..."). The distribution of the 412 songs by decade is presented in Table 1.

Table 1: Decadal distribution of rock songs used for this study $(\mathrm{N}=412)$.

\begin{tabular}{|lc|}
\hline Decade & Number of Songs \\
\hline $1960-1969$ & 19 \\
\hline $1970-1979$ & 59 \\
\hline $1980-1989$ & 103 \\
\hline $1990-1999$ & 167 \\
\hline $2000-2009$ & 64 \\
\hline
\end{tabular}

Within this specific set of songs, the most prolific author is Jimmy Buffett (44 songs), followed at a distant second by Jethro Tull (8 songs), and then The Beach Boys ( 7 songs). The Beastie Boys, Billy Joel, and Scanner (6 songs each); Fountains of Wayne and Insane Clown Posse (5 songs each); and Fate's Warning, Rush, Styx, and The Kinks (4 songs each). Many prominent rock musicians appear at least once, including The Beatles, Simon \& Garfunkel, the Bee Gees, Bob Marley, David Bowie, Jimi Hendrix, Neil Young, U2 and Van Halen.

The 412 lyrics were reviewed independently by each of this paper's authors. The results were then compared and discussed.

First of all, islands are the central topic of the text in only a small minority of tracks examined. In a larger minority, islands are not the text's focus, but play a prominent role. In the majority of lyrics, the reference to islands is much more superficial or passing. Nonetheless, a short and quick reference can be an important insight to the cognitive dimension of islandness, in terms of it being formulated automatically and unconsciously or perhaps simply mentioning an island place, assuming that this name would evoke the desired response in the listener. Given that, and within the context of the exploratory nature 
of this work, no analysis was completed regarding the extent to which or how often islands were mentioned; such an analysis would be fraught with difficulties anyway.

Instead, the lyrics were read to identify above all the way in which the islands were "thematized". In particular, for each citation of the words "island", "islands", "isle", or "isles", the context of use was considered, and therefore the way in which the islands were defined, qualified, characterized, and/or associated with specific realities (such as situations or feelings) by the authors of the lyrics themselves. A limited number of recurring thematic categories were then identified to which these definitions, qualifications, and/or connotations could be attributed. These categories were developed, discussed, and integrated several times during the analysis, modifying, combining, splitting them, and exploring their relationships.

Table 2: Distribution of 24 themes, organized as five meta-themes.

\begin{tabular}{|c|c|}
\hline Meta-theme & Theme \\
\hline \multirow{5}{*}{ space } & seclusion \\
\hline & desert \\
\hline & distance \\
\hline & link with water, sea, ocean \\
\hline & vulnerability \\
\hline \multirow{5}{*}{ lifestyle } & escape \\
\hline & adventure \\
\hline & exoticism \\
\hline & love and romance \\
\hline & intimacy \\
\hline \multirow{5}{*}{ emotions/psychology } & depression \\
\hline & fear \\
\hline & loneliness and despair \\
\hline & happiness \\
\hline & beauty \\
\hline \multirow{5}{*}{ symbolism } & spirituality \\
\hline & mystery \\
\hline & lost land \\
\hline & paradise, eden, utopia \\
\hline & artistry \\
\hline \multirow{4}{*}{ social-political relations } & dominance \\
\hline & social criticism \\
\hline & history \\
\hline & crime, violence, dystopia \\
\hline
\end{tabular}

In this sense, the analysis is neither deductive (as it was not based on a set of categories rigidly pre-established) nor inductive (as it was not based on a procedure starting from specific observations to arrive gradually at broader generalizations), but abductive (Hanson, 1965; Peirce, 1931-1935). The analysis is abductive because categories were identified that, in our opinion, could adapt as best as possible to the empirical material. Therefore, through a process of recognition and classification, typical of some approaches to qualitative 
analysis accepting categorization with a somewhat a priori approach (Denzin \& Lincoln, 2005), alongside a corresponding process of "condensation" and "denomination" from semantic field studies (Greimas, 1966), the many qualifications and connotations collected were consolidated into a limited number of "themes".

These themes numbered 24, with many themes often coexisting within the same lyrics. The 24 themes, in turn, were collated into five thematic clusters, or meta-themes, namely: "space", "lifestyle", "emotions," "symbolism", and "social-political relations". As with the themes, these meta-themes are not mutually exclusive: more than one can be inferred from the same song. See Table 2.

The five meta-themes comprising the 24 themes are presented in the next section. For each theme, one or more examples from the lyrics is provided to indicate illustrative, not comprehensive, evidence. For each theme, some references are provided, a posteriori, that can help to contextualize and communicate that theme; that is, the themes were developed abductively and then placed in the context of island-related literature.

\section{Island-related References and Themes}

Two major ways were identified in which islands are named and represented: (1) a reference to specific islands, real or fictional, which is discussed first below; and (2) evoking island-related ideas or themes as a general concept, without referring to or naming specific islands, discussed later.

\section{Reference to specific islands}

Some lyrics refer to specific, named islands, sometimes with and sometimes without attributed characteristics. Of particular prominence are islands engrained in cultures from which rock music emerges, with the most popular being New York City (covering Coney Island, Fire Island, and Manhattan); Rhode Island (which is actually not an island); and Ireland or parts or locations thereof (see Campbell \& Smyth, 2005; Smyth, 2005). The dominance of these locations might be influenced by the strong historical connections between Ireland and the northeastern USA, particularly New York City and Boston (Dolan, 2008), although Chicago also has strong Irish connections.

However, if lyrics were searched targeting key locational words such as "Caribbean" and "Pacific" or even "Australia", "Sydney", "New Zealand", or "Auckland" amongst other geographic names, then many more songs with lyrics covering those locations would be found. Similarly, even if "England", "Scotland", and "Wales" are accepted as not being islands, they could be interpreted as being island locations - as would London, Glasgow, Dublin, and other place names in the UK and Ireland; while "Britain" or "Great Britain" in song lyrics could be accepted as referring to an island. For this study, without one of the keywords "island", "islands", "isle", or "isles", the song would not be identified.

Other named islands in the lyrics are fictional, such as Jimmy Buffett's island called Kinja used throughout his album Don't Stop the Carnival, or Artension mentioning Atlantis in The City Is Lost. Similarly, if only the fictional island's name were mentioned without using one of the keywords, then the song lyrics would not be identified for this study. 
Moreover, a specific island may be often alluded to, but is unnamed, leaving the island idea, usually ideal, in the listener's imagination and with uncertainty regarding whether the island is real or fictitious. An example is "There's an island / In my soul / There's desire / Burning deep down, down below" (Warlock's Metal Tango). The lyrics are now moving from referring to specific islands into the island and islandness themes that are the core of this research.

As we researched the lyrics and connected them to themes and theories, it was clear that the mention of islands and island themes were complicated by the co-mingling of what criteria apply to islands and what criteria blend into mainlands. Many clear references to island themes simultaneously spoke about wider contexts, usually in terms of mainlanders or the mainland(s). The textual character of the music is determined by its subscription to values, ideals, objectives, and cultural meanings which bind them to the prevailing power structure.

\section{References to Island Themes}

This section extracts and clusters the main themes that emerged from the lyrics database, giving illustrative examples of lyrics. These themes and discussion of the lyrics are then embedded in past literature. As an exploratory work, prioritization of the themes was not conducted, so the order of the themes presented is not significant.

\section{Space}

Island literature provides many examples of viewing islands as different types of space and spaces, such as islands as paradoxical spaces (Stratford, 2003) and, in reference to artificial islands, "anxious spaces" (Jackson \& Della Dora, 2009).

$\underline{\text { Seclusion }}$

Islands serving as spaces of seclusion appeared in the song lyrics, such as:

Carly Simon - Island (2008)

I'm an island

Everyone can see that I'm an island

I've got ocean just about everywhere that I can see

And I'll be stranded unless you come to me

And I'm lonely

At times, reclusiveness is deliberately constructed:

Simon \& Garfunkel - I am a Rock (1966)

I've built walls,

A fortress deep and mighty,

That none may penetrate.

I have no need of friendship; friendship causes pain.

It's laughter and it's loving I disdain.

I am a rock,

I am an island. 
This theme, especially islands being used as prisons or traps or places of exile, voluntarily or involuntary, is a theme appearing extensively in the literature (e.g. Baldacchino, 2006; Tuan, 1995). Elements of contact, and lack of contact, with the mainland (or a mainland) also appear, for example:

Jethro Tull - Ears of Tin (1989)

Island in the city. Cut by a cold sea.

$[\ldots]$

I'm fresh from the out-world - singing the mainland blues.

\section{$\underline{\text { Desert }}$}

Reclusiveness connects to aspects of isolation, particularly the theme of "desert island" which recurs in rock music, as it does in novels such as Robinson Crusoe and the contemporary culture of the UK's Radio 4 program Desert Island Discs. An example of a song's lyrics covering this theme is:

Alanis Morissette - Front Row (1998)

One minute I want to banish you

the next I want to be on a deserted island with you with my three favorite cd's

\section{Distance}

Islands are frequently perceived as being marginal and remote from larger centres; both in terms of physical isolation (being a challenge to travel to), and in terms of being marginal, (being remote from and peripheral to decision-makers' thoughts and concerns). This theme appears within rock music with examples being:

Bob Dylan - Christmas Island (2009)

Let's get away from sleigh bells

Let's get away from snow

Let's make a break some Christmas, dear

I know the place to go

How'd ya like to spend Christmas on Christmas Island?

How'd ya like to spend the holiday away across the sea?

Death Cab for Cutie - Transatlanticism (2003)

I was standing on the surface of a perforated sphere

when the water filled every hole.

and thousands upon thousands made an ocean, making islands where no island should go.

$[\ldots]$

the rhythm of my footsteps crossing flood lands

to your door have been silenced forever more.

the distance is quite simply much too far for me to row

it seems farther than ever before

$[\ldots]$

I need you so much closer 
$\underline{\text { Link with water, sea, and ocean }}$

Many rock music lyrics clearly link islands to water, the sea, and the ocean, such as:

King Crimson - Islands (1971)

Earth, stream and tree encircled by sea

Waves sweep the sand from my island.

[...]

High weathered walls which fend off the tide

Cradle the wind

To my island.

$[\ldots]$

Waves sweep sand from my island,

From me.

$\underline{\text { Vulnerability }}$

Some aspects of island vulnerability emerged from some lyrics, even if this theme was not dominant in the database:

Anthrax-Medusa (1985)

Land of doom, world of sin

All subside, don't venture near

The island where she lives

Oh, she'll suck you in

Here Comes The Flood - Peter Gabriel (1977)

Lord, here comes the flood

We'll say goodbye to flesh and blood

If again the seas are silent

in any still alive

It'll be those who gave their island to survive

Drink up, dreamers, you're running dry.

The literature on various forms of island vulnerabilities-physical, social, and the interactions amongst them - and where those vulnerabilities arise from is extensive (e.g. Briguglio, 1995; Lewis, 1999, 2009). The enduring image (often created by islanders as much as non-islanders) can be of fragility due to disaster vulnerability. In recent years, climate change has ensconced themes of island vulnerability into many literary, scientific, and political mindsets - with or without islander support and connecting the vulnerabilities to both social and physical characteristics (Farbotko, 2005; McNamara \& Gibson, 2009). The rock music lyrics do not seem to yet reflect this shift in scientific discourse.

\section{Lifestyle}

Islands in rock music lyrics are frequently matched with various lifestyles, namely choices or situations related to the search or yearning for a particular quality of life or for personal and collective meaningful relations. 


\section{Escape}

Being reclusive or cloistered can be a lifestyle choice rather than a prison or a trap, as demonstrated by some lyrics:

Hot Hot Heat - Island of the Honest Man (2005)

Welcome to the island of the honest man

Do what you want - there is no need to impress us

Apache Indian - Peaceful Island (2000)

I want to live on a peaceful island - reap the fruits of the good seeds I grow

I want to live on a peaceful island - good vibes everybody watch now

Escape-related characteristics of islands are portrayed in various adventure stories (e.g. The Islander non-fiction by Gerald Kingsland and The Islander novel by John Maddox Roberts) and philosophical novels (e.g. Island by Aldous Huxley); they evince, amongst other aspects relevant to other themes, the freedom and independence to live as one chooses.

In another track, the escape theme is linked to a hopeless social and ecological situation, potentially also personifying "vulnerability":

The Kinks - Drift Away (1993)

It's apocalypse now

So we're waiting for the flood

(...)

And I'm losing my mind

I think I'll just drift away

To that island of my dreams

Live in total fantasy

Close my eyes and drift away

Adventure

Part of the escape to islands is the appeal to adventure, as shown by some lyrics:

Jimmy Buffett - Son of a Son of a Sailor (1978)

As the son of a son of a sailor,

I went out on the sea for adventure,

[...]

And the lady she hails from Trinidad,

Island of the spices.

[...]

Where it all ends I can't fathom, my friends.

If I knew, I might toss out my anchor.

Jefferson Airplane - Rock and Roll Island (1971)

Rock and roll island in the middle of the time seas

Back through time in firesign magnetics flow all around me

Travel for the sake of travel and "adrenaline pumping" is an integral part of this theme. 


\section{$\underline{\text { Exoticism }}$}

Some lyrics iconize islands as exotic locations for holidays and relaxing:

Scorpions - Holiday (1979)

Let me take you far away

You'd like a holiday

Exchange the cold days for the sun

$[\ldots]$

Longing for the sun you will come

To the island without name

Longing for the sun be welcome

On the island many miles away from home

Be welcome on the island without name

Longing for the sun you will come

Island destination marketing and branding maintains a high degree of S-3 (sun, sea, sand) tourism. Within the theme of exoticism, islands are ritually "aesthesicized, sanitized and anaesthetized" (Connell, 2003: 568).

\section{$\underline{\text { Love and Romance }}$}

S-3 tourism for islands and other locations has more recently become S-4 tourism in some places, with the additional 's' being 'sex' (e.g. Brennan, 2004). Examples are (i) seeking pedophilia or (ii) older women meeting younger islander 'boyfriends'. The song lyrics tend to highlight the positive aspects of island love and romance, without much indication of any darker sides. Examples are:

Bee Gees - Blue Island (1993)

Makes me love you

$[\ldots]$

On my blue island

See you on a blue island

Take you to a blue island

Coldplay - Warning Sign (2002)

You came back to haunt me and I realized

That you were an island and I passed you by

And you were an island to discover

Come on in, I've gotta tell you what a state I'm in

[...]

And the truth is

I miss you 
$\underline{\text { Intimacy }}$

Many songs highlight an affinity for islands to provide settings where close human relationships can flourish, with an example being:

311 - Welcome (1993)

I can't survive on a stupid nine to five I'd rather be poor

Writing tunes livin' on a commune

Kickin' it with my brothers and significant others

Life in pursuit of only money we think it's funny

The only thing that money it could ever bring to me

Would be some gifts for my friends follow me now

Trips for my family

The only thing I love is freedom

The people around me I need 'em

[...]

A Coney Island of the mind it's mine

I swipe the sweets strip the beats in the sunshine

These lyrics are particularly poignant because both "brothers" and "family" could be interpreted as blood relations or as metaphorical, such as a group of close friends. The interweaving of numerous island themes is also evident, including music and lifestyle alongside close and intimate relationships, as also explored in the following:

Arcwelder - Treasured Island (1999)

But it's not my fault

If your treasured island

Won't open up

To be filled with your love

$[\ldots]$

Rather be a help not your little whelp not a curse but a friend

End of my rope I can only hope things work out in the end

Island studies supports this view, in linking islands, in collective imagery and imagination, to various forms of intimate relationships, such as family, brotherhood or sisterhood, friendship, or more generally a sense of community that would seem to be more developed in an island setting (Guerron-Montero, 2006; Kana’Iaupuni \& Malone, 2006).

\section{Emotions (psychological)}

Islands are often discussed as being a category of the mind; social constructs which become tools for the social construction of reality (e.g. Baldacchino, 2007; deCerteau, 1984; Van Duzer, 2006). As Gillis (2004: 1) writes: "Western culture not only thinks about islands, but thinks with them", implying that even though islands may indeed be physical constructs, the social constructs can be, and often are, overlaid. The social constructs emerging from emotions, particularly desires regarding what islands are or are expected to provide, define many lyrics exemplifying aspects of how islands are viewed psychologically. That evokes various emotions as categorized in this section. 


\section{Depression}

Amongst the emotions linked to islands in rock music is depression, sometimes (although not inevitably) taking on a violent theme, such as:

Eminem - Tylenol Island (2000)

I'm homicidal, and suicidal, with no friends

$[\ldots]$

yo, yo, im only smilin when im violent, got on the plane wylin,

told the pilot to fly me to Tylenol Island

It remains unclear whether or not those living on (small) islands experience more extensive or severe depression (or other emotions) than those living elsewhere.

\section{$\underline{\text { Fear }}$}

In rock music, a link is sometimes set up between islands and a feeling of personal or collective fear, as shown by:

Fate's Warning - Orphan Gypsy (1985)

I'm a vagabond with a maelstrom mind

My blood has left me behind

So go away leave me alone.

If you look in my eyes you see only stone

I won't let you in I can lock you out,

In your world, your fallacy, I don't want desolate

Isle of debris

This phenomenon can be attributed to "nesophobia",or fear of islands (Lewis, 1995); or to a lingering historical association of islands as dangerous spaces where monsters may lurk (e.g. Weaver-Hightower, 2007).

\section{Loneliness and Despair}

Linked to the theme of being imprisoned by or on an island, island communities and peoples are sometimes represented in rock music as being subject to the emotional states of loneliness and despair:

All Living Fear - Someone Under Everyone (1996)

Schizophrenic suicide, but who is due to die.

[...]

Misery is a lonely state, and one I know so well.

Just an island of emotion, in a self tormenting hell.

Once again the bottle I try hard to cast, a simple plea for some help from outside.

Though I wait in hope I know it's all in vain, for I never put the message 
Jethro Tull - Ears of Tin (1989)

In the last hours of a sunset rendezvous -

Chill breeze against tide, that carries me from you.

Got a job in a southern city - got some lead-free in my tank.

Now I must whisper goodbye - I'm bound for the mainland.

Island in the city. Cut by a cold sea.

People moving on an ocean. Groundswell of humanity.

Beer (1997) and Stokes (2004) are examples from research corroborating this theme. As one of the icons, Napoleon was seen as living out his final days on the lonely isle of St. Helena (e.g. Bechet, 1928). In the modern day, isolated island communities are frequently framed as being psychologically demanding due to chronic loneliness and despair (Royle, 1989).

\section{$\underline{\text { Happiness }}$}

On the other hand, personal happiness in various forms is widespread in rock music mentioning islands:

Gong - The Isle of Everywhere (1973)

A bit a'cake

yum yum

haven't you forgotten

have another drink

have a larger!

Mike Oldfield - Foreign Affair (1983)

Take a trip in the air

To a tropical beach,

An island to reach.

$[\ldots]$

Drifting and free

On a mystical sea.

A wishful emotion,

A drop in the ocean.

The latter is particularly interesting in that many of the emotive connotations projected could easily apply to "loneliness/despair" and "depression" even though, as in this song, they are seen as the manifestations of a happiness associated with being carefree. This exemplifies how island characteristics might be generally accepted, but their interpretation is contextual. More simply, some people like certain island characteristics, assumed or real (e.g. isolation, smallness), and some do not. An island's size and degree of isolation, amongst other characteristics, will disappoint some and please others. 


\section{Beauty}

The pure visual pleasure of island scenery, whether tropical or not, is highlighted in some lyrics:

Depeche Mode - World in My Eyes (1990)

All the islands in the ocean

All the heaven's in motion

Let me show you the world in my eyes

Other themes present throughout this song are 'love/romance' and 'adventure (adrenaline pumping /travel for the sake of travel'. This song sees those themes as being part of island beauty. The view of islands as being aesthetically pleasing is common in the collective imaginary of islands and islandness (Connell, 2003; Gössling \& Wall, 2007).

\section{Symbolism}

The collective imagery and imagination of islands incorporates numerous symbolic references and allusions to the invisible, transcendent and ethereal. Gillis (2004) describes numerous aspects of the symbolism projected onto islands, leading to fascination with the island as a place in which the full, rich, and deep dreams and needs of humankind are seen to meld with the spiritual and esoteric.

\section{$\underline{\text { Spirituality }}$}

Islands are seen by some lyrics as locales where connections to the supernatural or other worlds exist:

George Harrison - Pisces Fish (2002)

And I'm a Pisces fish and the river runs through my soul

[...]

Like someone in there found the latest Pope

In a vat of beer that keeps pumping out with fury

While the churchbell ringer's tangled in his rope

There's a temple on an island

I think of all the Gods and what they feel

Shakepeare's The Tempest (Shakespeare, 1623) took place on an island where sorcery and illusion were used to achieve (spiritual and moral) righteousness. As far back as the Odyssey, many journeys, mythical or based in fact, occur over the sea, inevitably encountering islands and their spiritual implications, in the process. 


\section{Mystery}

Aspects of spirituality can link to mystery, where myth runs into legend and the supernatural becomes fantasy. Examples of song lyrics are:

Blind Guardian - Fast to Madness (1989)

White hair and red eyes

he's holding the crown

the king of the island

Elric of Melnibon?

he's born for destruction

he's ruled by the gods

eternal hero

the scale of the universe

$[\ldots]$

Destiny's calling him back to the island

And time? time is standing still

time is not real

Carpathian Forest - The pale mist hovers towards the nightly shores (1995)

Of the bleak and mysterious little isle,

Where no leaf has been touched by human hands.

Then I behold that island so fair,

Where the tree's lift their crown in prayers

To the golden glow of the evening sky

\section{Lost Land}

Part of the mystery and oddity of islands is those that are lost: they have either disappeared or were mythical in terms of being incorrectly identified as existing when they did not actually exist. Song lyrics covering this theme include:

Artension - The City is Lost (1997)

Stand at the ocean and hold out your hands history's callin' your name questions of ages are at your command for answers is why you came

And now you're searching for clues of a civilization

buried in time victim of early demise

The City is lost we search for Atlantis whatever the cost

The City is lost child of the sea for eternity tossed The City is lost

Donovan - Atlantis (1968)

The continent of Atlantis was an island which lay before the great flood in the area we now call the Atlantic Ocean.

$[\ldots]$

The great Egyptian age is but a remnant of the Atlantian culture.

The antediluvian kings colonized the world

Considerable literature, fictional and academic, analyzes lost isles such as Atlantis, and especially the mythologies that are built up around them (e.g. Donnelly, 1882; Forsyth, 1980). In terms of contemporary topics, the fiction, fact, and myth of islands being lost to 
climate change (e.g. Kelman, 2006; Webb \& Kench, 2010) does not appear in the rock music lyrics that were studied, but are nonetheless starting to appear in island-related popular culture. The 'lost land' theme contrasts with the occasional reference in lyrics to island building such as:

Jimi Hendrix - Voodoo Child (1968)

Well, I stand up next to a mountain

And I chop it down with the edge of my hand

Well, I pick up all the pieces and make an island

Might even raise a little sand

Real situations of island creation do occur, such as Surtsey off the coast of Iceland that appeared in 1963 (Thorarinsson, 1967). The legendary Isola Ferdinandea off the coast of Sicily, Italy, is an example of an emergent and then lost island: It emerged and then submerged due to volcanic activity within a few months in 1831 (Marzolla, 1831).

\section{$\underline{\text { Paradise, Eden and Utopia }}$}

Lost lands often have a nostalgic appeal; of what might have been in a perfect world. Examples of song lyrics covering island utopias are:

Fountains of Wayne - Utopia Parkway (1999)

I am the king of this island town

I'm on my own

I'm on my way

Down utopia parkway

Jefferson Starship - The baby tree (1970)

There's an island way out in the sea

where the babies they all grow on trees

and it's jolly good fun to swing in the sun

but ya gotta watch out if you sneeze sneeze

ya gotta watch out if you sneeze

Michael W. Smith - Lamu (1986)

Heading for peaceful shores

With a cast of strangers

To an island hideaway

$[\ldots]$

Where the world is still--it's ideal

Anything you dream is real

It's hotel paradise

This rock music view matches that of literary and religious traditions where islands are often the location of heaven (Bigalli, 2010) and have many utopian representations (e.g. Huxley's Island and Wright's Islandia). Stratford (2003) contrasts island utopias with island dystopias (more below). 


\section{$\underline{\text { Artistry }}$}

Part of the appeal of islands is often seen as the creativity that they spawn, expressed through art. This theme can be interwoven with others, such as Jimmy Buffett singing about making music, dance, and love on an island in Distantly in Love ("Lovely dancers swayin' to an island lullaby") and Morris' Nightmare:

Jimmy Buffett - Morris' Nightmare (1978)

Down in the islands where the happy folks stay

Everybody do what bwana jim say

He say it's ok, it's ok

You can do what you wanna

Do what you like

Twist a big ol' number

Ride a motorbike

It's alright, it's alright

Dance to the drum

Drink a lot of rum

Love till you come to a stop

Another example of song lyrics is:

America - Down to the Water (1977)

Island music

Sways with a palm tree

Not all island artistry is necessarily positive. Savatage's Sirens (1984) is about the islandrelated song of the sirens that lures sailors to their deaths.

The literature on island music (e.g. Baldacchino, 2011; Connell, 1999) corroborates this theme, especially in exploring its artistry in relation to such themes as identity, migration and globalization.

\section{Social-political relations}

Islands are sometimes (mis)represented as microcosms of larger scales with respect to society, including human relations and politics (Baldacchino, 2007, 2008; King, 2009). Many connections occur with earlier themes, such as different approaches to love/romance, how isolation or reclusiveness shape social and political relations, or songs that criticize or critique an island theme such as prisons, adventure or travel.

\section{$\underline{\text { Dominance }}$}

Among the lyrics examined, a theme of dominance over others and the ability to control others, because of island characteristics, has emerged. The title of Judas Priest's Island of Domination (1976) is a straightforward example. Regarding lyrics in a song:

Flotsam And Jetsam - No Place For Disgrace (1988)

Far to the east ruled the Samurai, mystic warrior class, Honorable brave, bark armoured man, donning hideous mask. 
700 years of reigning Japan, the masters of attack,

Dominators of the isle of dragons, fearsome military caste.

The particular configuration of islands renders them suitable sites for both utopian projects (as discussed above), but also totalitarian political projects, where the exercise of power and absolute control by despots or tight élites seems to be easier (Wegener, 2000; Winders, 1983). Within that context, in contrast to islands as paradise/Eden/utopia/heaven, islands can be viewed as places for ethically-suspect social experimentation, as in the case of Wells' The Island of Doctor Moreau (Wells, 1896).

\section{$\underline{\text { Social Criticism }}$}

Social criticism in the context of islands appears in, for instance, the following lyrics:

Bob Marley - Smile Jamaica (1976)

Feeling now, feeling down

This feeling wouldn't leave me alone

$[\ldots]$

Soulful town, roots people

Said I see that you're having fun

Rockin' to the roots man rocker

Oh island in the sun

$[\ldots]$

Help the children, help them right

Oh lord help them decide

Cast away that evil spell

Throw some water in the well

"Smile Jamaica" was written at the request of Jamaican Prime Minister Michael Manley. With heavy violence on the island surrounding the upcoming election, Marley agreed to write and perform the song. Marley never intended to be part of the "poli-tricks" of Manley or his political rival Edward Seaga, but the song served as a call for Jamaicans to end sectarial and partisan violence.

In wider literature, the perceived marginality and remoteness of islands can cause a weakening of political paradigms that are established and dominant elsewhere (Paterson, 2000). Many islands, as with other locations, have long histories involving social classes and castes followed by reactions against those. Trinidad and Tobago, Fiji, and Barbados illustrate the deep social and political conflict embedded in race and class (e.g. Beckles \& Watson, 1987; Young, 1992; Lorenz, 2007). As with Caribbean social protest in the spirit of the US civil rights movement, songs on islands have played roles in challenging the social order, while the desire for change is reflected in songs (Alleyne, 1994).

Another example promoting social change by overturning the established political order is:

Steel Pulse - Islands Unite (1994)

Unite, all the islands unite

And fight the wicked dem out of sight

First world, your bomb is ticking

Dirty deeds and politricking 
$[\ldots]$

Third world, it's time for switching

Watch how the table's turning

\section{History}

Within the representation of social order and changes to the social order on islands, history naturally plays a role. History, both factual and potentially apocryphal, is part of the storytelling function of songs. Islands and island representations are part of rock music telling stories. Two examples of lyrics are given. The first song recounts the tale of being forced by Cromwell to sail for Barbados in 1659 where the island is like a prison:

Flogging Molly - Tobacco Island (2004)

All to hell we must sail

For the shores of sweet Barbados

Where the sugar cane grows taller

Than the God we once believed in

Till the butcher and his crown

Raped the land we used to sleep in

Now tomorrow chimes of ghostly crimes

That haunt Tobacco Island

'Twas 1659 forgotten now for sure

They dragged us from our homeland

With the musket and their gun

Cromwell and his roundheads

Battered all we knew

Shackled hopes of freedom

We're now but stolen goods

Darkens the horizon

Blackened from the sun

This rotten cage of Bridgetown

Is where I now belong

The other song romanticizes a woman's background or characteristics emerging from Scottish islands over the past millennium.

Jethro Tull - European Legacy (1984)

I strain my eyes - against the southern light advancing

On whiter cliffs I'm high, the sea birds roll and tumble as they fly

I hear distant mainland music echo in my island ears

My feet begin to move instinctly

To the warmer beat of my European Legacy 
Crime, Violence and Dystopia

Some song lyrics express dystopian views of islands. Examples are:

Grip Inc. - Vindicate (1999)

Escaping with no significance

Stand by your killing whores

Mentor filled with bitterness

Watch your back

Misleading angel spew out metaphors

Sickening beauty mystic island charms

$[\ldots]$

Something inside me has died

Smashed down criminally denied

Elton John - Island Girl (1975)

Island girl, what you're wantin' with the white man's world

Island girl, black boy wants you in his island world

He wants to take you from the racket boss

He wants to save you but the cause is lost

Island girl, island girl, island girl

Tell me what you're wantin' with the white man's world

Stratford (2003) discusses the challenges of island dystopias, contrasted with island utopias. Many traits of dystopias link to criminal activity, lack of safety and security, and war. The implication is not just the existence of danger and lawbreakers, but that they are permitted to exist - even on an island. That links to themes such as "Fear" and "Dominance".

\section{Main Findings: A First Discussion}

Based on the data and interpretation from the previous section, we can present a first discussion regarding the portrayal of islands, islandness, and island characteristics in rock music lyrics. In particular, our work tends to show an island place for music. Geographers might term it "space and place", which here could be interpreted as "music and place". Space is presented not simply as a site, or locus; that is, an island where music happens. Rather, we found suggestions of different spatialities of music related to the music/lyrics and the place of islands as focus (Ronström, 2011).

The references to islands should not necessarily be considered spurious. While the image of islands in rock music might spawn notions of weak compared to strong, passive compared to active, risk compared to safety, fragile compared to robust, peripheral compared to central, and/or dependent compared to independent, many images of islands in music lyrics are ambiguous. According to rock music, islands are not just places for survivors and castaways. Rather, the lyrics show that musicians, like society, can perceive islands as sensations, communities, images, tangible places, modes of political power, and fun and desirable locations.

Despite hints of vulnerability and resilience, these themes are not developed in the lyrics to the same extent or depth as in the larger scholarly literature on the topics of island vulnerability and resilience (e.g. Briguglio, 1995; Lewis, 1999, 2009). Perhaps vulnerability 
and resilience are largely academic constructs, subject to much scholarly debate that does not always translate into usefulness on the ground, especially for islanders (e.g. Baldacchino, 2004a). And many lyrics mention islands and islandness in passing, not particularly exploring themes to any great depth. While it is relatively straightforward to discuss themes of beauty and fear, amongst others, in a superficial manner, vulnerability and resilience might require more thought and interpretation, which is not necessarily the point of much rock music.

Similarly, not all assumed geographical aspects of islands emerge from rock music lyrics. One interesting aspect regards the lyrics' absence of mentioning or implying the size of the islands, in that we wonder why size is not a larger (no pun intended) island theme in rock music lyrics. Small islands, bounded spaces limited in size, may also be limited in resources and thus, in political leverage - although that is not always the case. To believe that small islands are places without power is to ignore the political role of the African Diaspora and of reggae, calypso, and ska music, especially in the Caribbean.

Scholars might question the impact of rock music lyrics on society and culture. From our analysis, we posit that the relevance of lyrics should not be dismissed. Certainly, one could argue that music has too much power over many people. Tipper Gore posed this argument in the 1980s and many in U.S. society supported her claims (Brill, 2010). To many, the word "music" is about revolution, which is a dangerous proposition to the status quo:

One only has to observe what rock n' roll has done to cause our young people to riot and participate in social rebellion, chaos and bedlam, to understand how significantly music fits into any revolutionary era (Noebel, 1974: 115).

As Thoreau (1854: 338) warned, "Even music may be intoxicating. Such apparently slight causes destroyed Greece and Rome, and will destroy England and America".

The results here lend some support to such views of rock music's aim to influence, but also provide views regarding why musicians choose to enter into social debate and try to influence society. Regarding islands and islandness, musicians appear to be more than participants or voyeurs. The music can be seen as an allegory for what musicians have experienced and want to experience from islands. Often, it appears as if the use or invocation of an island or island ideas is assumed to convey the meaning without further descriptions. That is demonstrated by how often specific, named islands - real or not - turn up in rock music lyrics without attributed characteristics or further information.

In parallel, the real or metaphorical idea of an island (or islandness) frequently appears in general terms, not always considering much about the specific island characteristics or meanings. Often the notion is almost whimsical, simply using the word because a place or idea was needed in the lyrics. Why choose an island? Potentially because of the assumed characteristics imbued in the word - or potentially because it fits the metre, or because the artist comes from, lives on, vacationed on, or read about an island.

In that sense, the use of islands in rock music lyrics appears to be no different than any other named place or geographic feature. Such place names are often stated directly, such as Sting describing "I'm an Englishman in New York". That is a song about a man from England, sometimes considered to be on an island, on the island of Manhattan, yet the song neither mentions nor implies island characteristics, even if the Englishman feels like an 
island adrift in a sea of New Yorkers / Americans. At other times, the geographic feature is generic, such as a town, a park, or a desert, personified by The Eagles' "dark desert highway" noting that Hotel California, to a large degree, displays many island characteristics. Many of the lyrics mentioning islands also refer to other geographic features, such as a mountain, city, or the sea, as descriptors.

Within the context of different geographic representations in rock music, the themes and meta-themes presented above show islands as one "social tool", cognitive in nature, to anchor, develop, and project ideas, feelings, world views, personal life projects, and collective ideals of good or bad. Given the diversity of the themes and meta-themes, the portrayal of islands as a cognitive object or social construct is a complex venture.

Does that differ for islander artists when compared to mainlander artists? This analysis does not permit any comment on how islander rock music artists use the word or concept of "island" compared to non-islander rock music artists. In fact, the proportional representativeness of islanders compared to non-islanders in the artists in our database is unknown, because we have no reliable data indicating how many rock artists would be considered islanders and how many would not. After all, significant ambiguities exist in defining an "islander". Ian Anderson of Jethro Tull lived and worked on the Isle of Skye for many years ${ }^{3}$ : could the island and non-island influences on that music be analyzed and separated? Probably not.

We further suggest that great care is needed in assuming that an islander would compose rock music and lyrics different from a non-islander. The literature notes that rock music culture tends to be an urban culture of continental and global perspectives (Anckar 2008). Björk is a global phenomenon and draws on standard rock music culture, and the same could potentially be said of reggae (although that is arguable), despite their island origins (Hills 1996).

The interest in islands in rock music (and possibly other genres) from islanders and nonislanders alike could be interpreted as the expression of a search for locations or territories, real or not, where one can find a refuge and exercise some form of control (e.g. the lyrics quoted earlier "And you were an island to discover...") (Coldplay, Warning Sign, 2002). This search for (island) territories of refuge and control is expressed in several of the themes discussed here, such as tourism/travel/adventure. These topics include the physical and emotional themes that enhance the body as the first, basic "special home" for individuals (until negative traits emerge, such as exploitation and violation of the female body) (Quaranta, 2010).

The role of rock music in this "re-territorialization" of body, mind, and place could be an underlying component of islandness as an important presence in the collective imagery and imagination of contemporary society, as epitomized through rock music. Overall, the rock music lyrics analyzed a wide range of references to and indications of islands, including consolidated images, metaphors or even stereotypes, adding another art form to the long list which has been examined through the lens of islands and islandness.

\footnotetext{
${ }^{3}$ Thanks to Graeme Robertson for this information and other suggestions.
} 


\section{Conclusions and Research Paths}

This paper is an initial exploration into how rock music portrays islands, islandness, and island characteristics. Rock music lyrics have been read and examined in order to construct an emergent thematic typology, which is nevertheless inspired by what we know about island literature. The analysis tends to support the enduring importance of islands and islandness as social constructs and tools for the social construction of reality. To continue to gain insights, some further research directions are proposed.

First, other genres of music could be explored. Examples are opera, musical theatre, and jazz. For opera in particular, keywords across many languages would be needed. Analyses could then be completed for operas, and other genres, from particular languages, composition schools, and time periods. Classical music would be an intriguing category, but that might need to be separated into two categories: choral works, again across multiple languages, and the titles of pieces and movements, for instance Rachmaninov's The Isle of the Dead Op. 29 or Debussy's L'Isle Joyeuse. Folk music and world music would be exciting genres to examine across languages and dialects since their lyrics are frequently evocations about one's home and land (e.g. Connell, 1999).

Some of these extensions apply to furthering the study of rock music presented here. The lyrics selected for this paper were in English only, despite many rock bands singing in other languages such as Ultima Thule's Ensamt Öga in Swedish, and JadaL's Ya Ahla 3youn in Arabic. A further division by language could be examined with regards to local dialects, such as comparing how rock music and other genres portray islands, islandness, and island characteristics in English; in different versions of English, such as the Eastern Caribbean or the South Pacific; and in different Creoles. As part of this work, a systematic database of lyrics across languages that refer to islands could be created and constantly updated. Based on this rich corpus, a deeper analysis could be performed.

The choice of genre category is important: the same music genre usually has different characteristics in different eras and geographical locations (e.g. Connell \& Gibson, 2003; Lena \& Peterson, 2008). The level of subdivision within each genre could also be considered. For rock music, is it useful to analyze lyrics by subdivisions such as Drone Metal, Math Rock, Stoner Metal, and Stoner? How are rock, rock and roll, metal, punk, and others separated?

Finally, several of the prominent themes have suggested other terms that are often associated with islands and islandness, most directly the sea, the ocean, the coast, waves, and water. Often, lyrics might imply an island or island characteristics without using a word involving "island" or "isle" (An Englishman in New York was discussed earlier). Many songs are about island themes or locations without using such words, with two examples being Billy Ocean's Caribbean Queen and Rick Wakeman's instrumental song Pacific Paradise - the latter begging the question, alluded to earlier for classical music, about incorporating songs without lyrics into the analysis. From databases of lyrics and classification systems, other content analysis techniques - quantitative and qualitative - can be considered.

Many dimensions thus remain to be explored in the intersection of island studies and the study of music lyrics. That extends to compare music analysis with completed islandrelated analysis of other art forms such as poetry, literature, and wider iconization in art 
(Lomuto, 2003; Maeder et al., 2005; Ouspensky \& Lossky, 1982). As a first step towards such work, we hope that this study has provided a useful baseline.

\section{Acknowledgements}

We have welcomed rigorous and helpful comments provided by anonymous referees. Opinions expressed by authors are their own and do not necessarily represent their institutions.

\section{References}

Alleyne, M. (1994) 'Positive Vibration?', Caribbean Studies, Vol. 27, Nos. 3/4, pp. 224241.

Anckar, C. (2008) 'Size, Islandness, and Democracy: A Global Comparison', International Political Science Review, Vol. 29, No. 4, pp. 433-459.

Baldacchino, G. (2004a) 'Moving away from the Terms Vulnerability and Resilience in Small Islands', Wise Coastal Practices for Sustainable Human Development Forum, Thursday, 11 March 2004, www.csiwisepractices.org/?read=490

Baldacchino, G. (2004b) 'The Coming of Age of Island Studies', Tijdschrift voor Economische en Sociale Geografie, Vol. 95, No. 3, pp. 272-283.

Baldacchino, G. (ed.) (2006) Extreme Tourism: Lessons from the World's Cold Water Islands, Amsterdam, Elsevier.

Baldacchino, G. (2007) 'Introducing a World of Islands' in G. Baldacchino (ed.) A World of Islands: An Island Studies Reader, Charlottetown, Canada and Luqa, Malta, Institute of Island Studies and Agenda Academic, pp. 1-29.

Baldacchino G. (2008) 'Studying Islands: On Whose Terms? Some Epistemological and Methodological Challenges to the Pursuit of Island Studies', Island Studies Journal, Vol. 3, No. 1, pp. 37-56.

Baldacchino, G. (ed.) (2011) Island Songs: A Global Repertoire. Lanham MD, Scarecrow Press.

Bechet, P.E. (1928) 'Napoleon: His Last Illness and Postmortem', Bulletin of the New York Academy of Medicine, Vol. 4, No. 4, pp. 497-502.

Beckles, H. \& Watson, K. (1987) 'Social Protest and Labour Bargaining: The Changing Nature of Slaves' Responses to Plantation Life in $18^{\text {th }}$ Century Barbados', Slavery \& Abolition, Vol. 8, No. 3, pp. 272-293.

Beer, G. (1997) 'The Making of a Cliché: 'No Man is an Island', European Journal of English Studies, Vol. 1, No. 1, pp. 33-47.

Berger, P. L. \& Luckmann, T. (1966) The Social Construction of Reality: A Treatise in the Sociology of Knowledge, Garden City NY, Anchor Books. 
Bigalli D. (2010) Il Mito della Terra Perduta: Da Atlantide a Thule, Rome, Bevivino.

Braithwaite, J. (1979) Inequality, Crime, and Public Policy, New York, Routledge and Kegan Paul.

Brennan, D. (2004) What's Love Got to do With it? Transnational Desires and Sex Tourism in the Dominican Republic. Durham NC, Duke University Press.

Briguglio, L. (1995) 'Small Island Developing States and Their Economic Vulnerabilities', World Development, Vol. 23, No. 9, pp. 1615-1632.

Brill, M.T. (2010) America in the 1980s, Minneapolis MN, Twenty First Century Books.

Campbell, S. \& Smyth, G. (2005) Beautiful Day: Forty Years of Irish Rock, Ireland, Cork University Press.

Charlton, C. (2003) Rock Music Styles: A History, $3^{\text {th }}$ Edition, Boston MA, McGraw-Hill.

Cheadle, N. (2009) 'Figurations of Islandness in Argentine Culture and Literature: Macedonio Fernández, Leopoldo Marechal, and César Aira', Island Studies Journal, Vol. 4, No. 2, pp. 203-224.

Connell, J. (1999) “My island home': The Politics and Poetics of the Torres Strait' in R. King \& J. Connell, eds., Small Worlds. Global Lives: Islands and Migration, London, Pinter, pp. 195-212.

Connell, J. (2003) 'Island Dreaming: The Contemplation of Polynesian Paradise', Journal of Historical Geography, Vol. 39, No. 4, pp. 554-581.

Connell, J. \& Gibson, C. (2003) Sound Tracks: Popular Music, Identity and Place, London, Routledge.

Curtis, J.M. (1987) Rock Eras: Interpretations of Music and Society, 1954-1984, Madison WI, Popular Press.

Dawe, K. (ed.) (2004) Island Musics, New York, Berg.

De Certeau, M. (1984) The Practice of Everyday Life, Berkeley CA, University of California Press.

Deleuze, G. (2004) Desert Islands and Other Texts (1953-1974), translated by Mike Taormina, Cambridge MA, MIT Press.

Deleuze G., \& Guattari F. (1986) A Thousand Plateaus, Minneapolis MN, University of Minnesota Press.

Denzin, N.K. \& Lincoln, Y.S. (Eds.) (2005) The Sage Handbook of Qualitative Research, Thousand Oaks CA, Sage. 
Dolan, J.P. (2008) The Irish Americans: A History, New York, Bloomsbury Press.

Donnelly, I. (1882) Atlantis: The Antediluvian World, New York, Harper \& Brothers.

Farbotko, C. (2005) 'Tuvalu and Climate Change: Constructions of Environmental Displacement in the Sydney Morning Herald', Geografiska Annaler B, Vol. 87, No. 4, pp. 279-294.

Farr, R. M. \& Moscovici, S. (Eds.) (1984) Social Representations, Cambridge, Cambridge University Press.

Forsyth, P.Y. (1980) Atlantis: The Making of Myth, Montreal QC, McGill-Queen's University Press.

Freedman, D.A., Pisani, R. \& Purves, R.A. (1998) Statistics, 3rd ed., NewYork, W.W.

Norton.

Geografiska Annaler, Series B: Human Geography. (2005) 'Special issue on "Islands: Objects of Representation', Vol. 87, No. 4, pp. 247-305.

Geographical Review. (2007) Special issue on 'Islands', Vol. 97, No. 2, pp. 153-306.

Gillis, J.R. (2004) Island of the Mind: How the Human Imagination Created the Atlantic World, New York, Palgrave Macmillan.

Gössling, S. \& Wall, G. (2007) 'Island Tourism' in G. Baldacchino (ed.) A World of Islands: An Island Studies Reader, Charlottetown, Canada and Luqa, Malta, Institute of Island Studies and Agenda Academic, pp. 429-453.

Greimas, A.J. (1966) Sémantique structurale: Recherche de methode, Paris, Larousse.

Guerron-Montero, C. (2006) 'Can't Beat Me Own Drum in Me Own Native Land', Anthropological Quarterly, Vol. 79, No.4, pp. 633-655.

Hanson, N.R. (1965) "Notes toward a logic of discovery", in R. J. Bernstein (ed.) Perspectives on Peirce (pp.42-65), New Haven CT, Yale University Press.

Hills, T.L. (1996) 'Island Matters, Islands Matter: International Institutional Responses to the Analysis of Problems and their Solutions', Geographische Zeitschrift, Vol. 84, No. 1, pp. 67-73.

Holm, B. (2000) Eccentric Islands: Travels Real and Imaginary, Minneapolis MN, Milkweed.

Jackson, M. \& Della Dora, V. (2009) 'Dreams so big only the Sea can hold them: Manmade Islands as Anxious Spaces, Cultural Icons, and Travelling Visions', Environment and Planning A, Vol. 41, No. 9, pp. 2086-2104. 
Kana'Taupuni, S.M. \& Malone, N. (2006) 'This Land is My Land: The Role of Place in Native Hawaiian Identity' in G.W. Frazier \& and E.L.Tettey-Fio (Eds.), Race, Ethnicity and Place in a Changing America, Binghampton NY, Global Academic Publishing, pp. 287-300.

Kelman, I. (2006) 'Island Security and Disaster Diplomacy in the Context of Climate Change', Les Cahiers de la Sécurité, Vol. 63, No. 1, pp. 61-94.

King, R. (2009) 'Geography, Islands and Migration in an Era of Global Mobility', Island Studies Journal, Vol. 4, No. 1, pp. 53-84.

Lena, J.C. \& Peterson, R.A. (2008) 'Classification as Culture: Types and Trajectories of Music Genres’, American Sociological Review, Vol. 73, No. 5, pp. 697-718.

Lewis, B.D. (1995) 'Mother Nature Versus the Amazons: Marina Tsvetaeva and Female Same-Sex Love', Journal of the History of Sexuality, Vol. 6, No. 1, pp. 62-88.

Lewis, J. (1999) Development in Disaster-prone Places: Studies of Vulnerability, London, Intermediate Technology Publications (Practical Action).

Lewis J. (2009) 'An Island Characteristic: Derivative Vulnerabilities to Indigenous and Exogenous Hazards', Shima: The International Journal of Research into Island Cultures, Vol. 3, No. 1, pp. 3-15.

Leyshon, A., Matless, D. \& Revill, G. (2001) 'The Place of Music', Transactions of the Institute of British Geographers, Vol. 20, No. 4, pp. 423-433.

Lomuto, M. (2003) 'Iconicity in Music', European Journal for Semiotic Studies, Vol. 15, Nos. 2-4, pp. 372-385.

Lorenz, A. (2007) Lyrics and the Law: The Constitution of Law in Music, Lake Mary FL, Vandeplas Publishing.

Maeder, C., Fischer, O. \& Herlofsky, W.J. (2005) Outside-in, Inside-out: Iconicity in Language and Literature: Vol. 4, Amsterdam, John Benjamins Publishing.

Manderson, D. (2000) Songs without Music: Aesthetic Dimensions of Law and Justice. Berkeley CA, University of California Press.

Marzolla, B. (1831) Descrizione dell'Isola Ferdinandea al mezzo-giorno della Sicilia, Naples, Reale Officio Topografico.

McNamara, K.E. \& Gibson, C. (2009) "We do not want to leave our Land': Pacific Ambassadors at the United Nations resist the Category of 'Climate Refugees", Geoforum, Vol. 40, No. 3, pp. 475-483.

Noebel, D. (1974) The Marxist Minstrels: A Handbook on Communist Subversion of Music, Tulsa OK, American Christian College Press. 
Ouspensky, L. \& Lossky, V. (1982) The Meaning of Icons, Crestwood NY, St. Vladimir's Seminary Press.

Paterson, R. (2000) 'The Primary Sector: Problem and Opportunity for Islands' in G. Baldacchino \& D. Milne (Eds.) Lessons from the Political Economy of Small Islands: The Resourcefulness of Jurisdiction, Basingstoke, Macmillan, pp. 159-171.

Peirce, C.S. (1931-1935) The Collected Papers of Charles S. Peirce (8 Vols.), Cambridge MA, Harvard University Press.

Powell, R.R. \& Connaway L.S. (2010) Basic research Methods for Librarians, Santa Barbara CA, Libraries Unlimited.

Quaranta, G. (2010) 'Proposta per un secondo documento per il Programma unificato di ricerca di base' [Proposal for a second document for the Unified Program of Basic Research], unpublished draft. January 9, General Theory Course, Scuola di Sociologia e Scienze Umane [School of Sociology and Human Sciences], Rome, Italy.

Ronström, O. (2011) 'Gotland: Where "Folk Culture" and "Island" Overlap' in G. Baldacchino (Ed.) Island Songs: A Global Repertoire, Lanham MD, Scarecrow Press, pp. 245-259.

Royle, S.A. (1989) 'A Human Geography of Islands' Geography, Vol. 74, No. 2, pp. 106116.

Royle, S.A. (2007) 'Definitions \& Typologies' in G. Baldacchino (Ed.) A World of Islands: An Island Studies Reader, Charlottetown, Canada and Luqa, Malta, Institute of Island Studies and Agenda, pp. 33-56.

Said, E. (1992) Musical Elaborations, Oxford, Oxford University Press.

Shakespeare, W. (1623) 'The Tempest' in J. Heminges and H. Condell (Eds.) The Workes of William Shakespeare, containing all his Comedies, Histories, and Tragedies: Truely set forth, according to their first Originall, London, Isaac Iaggard and Ed. Blount, pp. 1-19.

Smyth, G. (2005) Noisy Island: A Short History of Irish Popular Music, Ireland, Cork University Press.

Stokes, M. (2004) 'Music and the Global Order', Annual Review of Anthropology, Vol. 33, pp. 47-72.

Stradling, R. \& Hughes, M. (1993) The English Musical Renaissance 1860-1940: Construction and Deconstruction, London, Routledge.

Stratford, E. (2003) 'Flows and Boundaries: Small Island Discourses and the Challenge of Sustainability, Community and Local Environments', Local Environment, Vol. 8, No. 5, pp. 495-499. 
Thomas, S. (2010) 'Nissopoesis: A spatializing and narrativizing practice', paper presented at conference Finding their Place: Islands in Social Theory, Islands Commission, International Geographical Union (IGU) with the Department of Human Geography, Lund University, the island of Ven, Sweden, August 27-30.

Thorarinsson, S. (1967) 'The Surtsey Eruption and Related Scientific Work', Polar Record, Vol. 13, No. 86, pp. 571-578.

Thoreau, H.D. (1854) Walden, Boston MA, Ticknor \& Fields.

Tuan, Y.F. (1995) 'Island Selves: Human Disconnectedness in a World of Interdependence', Geographical Review, Vol. 85, No. 2, pp. 229-239.

Van Duzer, C. (2006) 'From Odysseus to Robinson Crusoe: A Survey of Early Western Island Literature', Island Studies Journal, Vol. 1, No. 1, pp. 143-162.

Webb, A.P. \& Kench, P.S. (2010) 'The Dynamic Response of Reef Islands to Sea-Level Rise: Evidence from Multi-decadal Analysis of Island Change in the Central Pacific', Global and Planetary Change, Vol. 72, No. 3, pp. 234-246.

Weaver-Hightower, R. (2007) Empire islands: castaways, cannibals, and fantasies of conquest. Minneapolis MN, University of Minnesota Press.

Wegener F. (2000) Das Atlantidische Weltbild. Nationalsozialismus und Neue Rechte auf der Suche nach der versunkenen Atlantis, Gladbeck, Kulturförderverein Ruhrgebiet.

Wells, H.G. (1896) The Island of Doctor Moreau. New York, Stone \& Kimball.

Wicke P. (1990) Rock Music: Culture, Aesthetics, and Sociology, Cambridge, Cambridge University Press.

Winders, J.A. (1983) 'Reggae, Rastafarians and Revolution: Rock Music in the Third World', The Journal of Popular Culture, Vol. 17, No. 1, pp. 61-73.

Young, J.A. (1992) 'Social Protest and Spontaneous Development: A Contemporary Social Movement in Fiji', Pacific Studies, Vol. 15, No. 3, pp. 77-114. 